\title{
Emotionalisation of contemporary media discourse: A research agenda
}

\author{
Franco ZAPPETTINI ${ }^{1}$, Douglas M. PONTON ${ }^{2,3}$ and Tatiana V. LARINA ${ }^{3}$ \\ ${ }^{1}$ University of Liverpool \\ Liverpool, UK \\ ${ }^{2}$ Catania University \\ Catania, Italy \\ ${ }^{3}$ Peoples' Friendship University of Russia (RUDN University) \\ Moscow, Russia
}

\begin{abstract}
This special issue continues the discussion of the role of emotion in discourse (see Russian Journal of Linguistics 2015 (1) and 2018, 22 (1)) which, as testified by the burgeoning body of literature in the field, has become more prominent in different spheres and contexts of public life. This time we focus on emotionalisation of media discourse. We highlight the intensification of emotions in media and, showcasing contributions from international authors, critically reflect on constructions, functions and pragmatic purposes of emotions in media discourse. Our aim is to investigate emotions in the media from semiotic, pragmatic and discursive perspectives against the contemporary sociopolitical background in which traditional notions concerning the role of media are being noticeably changed. In this introductory article, we also put forward an agenda for further research by briefly outlining three main areas of exploration: the logics of media production and reception, the boundaries of media discourse, and the semiotic resources deployed to construct emotionality. We then present the articles in this issue and highlight their contributions to the study of linguistic representations of emotions. We then summarise the main results and suggest a brief avenue for further research.
\end{abstract}

Keywords: emotions, emotionalisation, media discourse, persuasion, media linguistics, Critical Discourse Analysis, Multimodal Analysis

\section{For citation:}

Zappettini, Franco, Douglas M. Ponton \& Tatiana V. Larina. 2021. Emotionalisation of contemporary media discourse: A research agenda. Russian Journal of Linguistics 25 (3). 586-610. https://doi.org/10.22363/2687-0088-2021-25-3-586-610 


\title{
Эмоционализация современного медиадискурса: исследовательская повестка дня \\ Ф. ЗАППЕТТИНИ ${ }^{1}$, Д.М. ПОНТОН ${ }^{2,3}$, Т.В. ЛАРИНА ${ }^{3}$ \\ ${ }^{1}$ Ливерпульский университет \\ Ливерпуль, Великобритания \\ ${ }^{2}$ Катанийский университет \\ Катания, Италия \\ ${ }^{3}$ Российский университет дружбы народов (РУДН) \\ Москва, Россия
}

\begin{abstract}
Аннотация
В этом специальном выпуске продолжается обсуждение роли эмоций в дискурсе (см. Russian Journal of Linguistics 2015, № 1 и 2018, вып. 22, №1), которая, как свидетельствует растущий объем литературы в этой области, стала более заметной в разных сферах и контекстах общественной жизни. На этот раз мы обращаемся к эмоционализации медиадискурса. Авторы статей данного выпуска анализируют способы выражения эмоций, их функции и прагматические цели в медийном дискурсе и приводят многочисленные факты, свидетельствующие об усилении эмоционализации в средствах массовой информации. Наша цель - исследовать эмоции в СМИ с семиотической, прагматической и дискурсивной точек зрения на фоне современного социально-политического контекста, в котором традиционные представления о роли средств массовой информации претерпевают заметные изменения. Мы также намечаем направления дальнейших исследований, выделяя три основные области, касающиеся (1) логики производства и восприятия медиапродукта, (2) границ медиадискурса, (3) семиотических ресурсов, используемых для создания эмоциональности. Далее в статье мы кратко представляем исследования авторов этого выпуска и отмечаем их вклад в изучение лингвистических репрезентаций эмоций. В заключении подводим основные итоги и предлагаем пути дальнейших исследований.
\end{abstract}

Ключевые слова: эмоции, эмоционализация, убеждение, медиадискурс, медиалингвистика, критический дискурс-анализ, мультимодальныий анализ

\section{Для цитирования:}

Zappettini F., Ponton D.M., Larina T.V. Emotionalisation of contemporary media discourse: A research agenda. Russian Journal of Linguistics. 2021. Vol. 25. № 3. P. 586-610. https://doi.org/10.22363/2687-0088-2021-25-3-586-610

\section{Introduction}

Emotions are at the basis of human interaction and communication and, as testified by numerous studies in the field of psychology, sociology and linguistics, their role has been noticeably increasing in recent years (e.g. Alba-Juez \& Larina 2018, Lerner \& Rivkin-Fish 2021, Mackenzie \& Alba-Juez, 2019, Scherer 2005, Shakhovsky 2008, 2018, Wetherell 2012, 2015, Wirth \& Schramm 2015). This body of research has highlighted "the pervasive presence of emotionality in contemporary culture, where emotions become more important and formative than anything else" (Lerner \& Rivkin-Fish 2021: 1), while it has shown how both explicit emotional expressions and implicit means of emotional appeal have broadened their functions in different social domains and discourses. The term emotionalisation has thus been used to refer to the legitimization and intensification 
of emotional discourse in collective spheres of life (Ahmed 2014, Holmes 2010, Lerner \& Rivkin-Fish 2021, Sieben \& Wettergren 2010, Woodward 2009). As well as in everyday interpersonal interaction, emotionalisation of institutional, professional and civic domains has been identified (Lerner \& Rivkin-Fish 2021). Emotions are highly relevant in academic discourse (e.g. Gretzky \& Lerner 2021, Larina \& Ponton 2020, forthcoming; Lerner, Zbenovich \& Kaneh-Shalit 2021), in classroom settings (e.g. El-Dakhs et al. 2019), in digital communication (e.g. Maíz-Arévalo 2018, Jus 2018). Appeals to emotions have increasingly been featured in what are otherwise regarded as non-emotional genres of discourses, for example diplomatic, economic and financial discourses (e.g. Belyakov 2015, Mackenzie 2018, Zappettini \& Unerman 2016). Several scholars have also pointed out that it is extremely challenging to disentangle affect from ideology, since the feelings and ideas that trigger the emotions are closely bound up together (Wetherell 2012, 2015). As Breeze (2020: 22) notes, emotions are therefore an inherent component of political discourse too, "precisely because of [their] emotional/affective impact on target audiences" (see also Breeze 2019). Emotionalisation has also been pervasive in the media (e.g. Alba-Juez \& Mackenzie 2019, Altheide 2002, 2006, Antipova et al. 2021, de Marlangeon 2018, Bartlett \& Gentile 2011, Döveling et al. 2011, Furedi 2018, Kopytowska \& Chilton 2018, Schwab \& Schwender 2011, Vishnyakova \& Polyakova 2017) where emotions can be used as a fundamental means of persuasion, since they are essential in understanding how media messages are processed, and have considerable impact on individual behaviour and public social life (Döveling, von Scheve \& Konijn 2011).

Our special issue focuses on the above-mentioned dynamics as they are constructed by and reflected in the media. Our aim is thus to investigate emotions in the media from semiotic, pragmatic and discursive perspectives, against the contemporary socio-political background in which traditional notions concerning the role of media, its ownership and professional practices, are being revolutionized by new technologies which allow, for example, for more interactive forms of communication performed through social media (Assimakopoulos 2018, BouFranch \& Garcés-Conejos Blitvich 2019, Breeze 2020). On the back of these changes, we see the emergence of new participatory opportunities (for example citizens' journalism), which has the potential to democratise the informative function that has typically distinguished traditional forms of media. New media platforms, meanwhile, pose new challenges to how information is produced, distributed and consumed, as distinctions between public and private mediated spaces have increasingly blurred. These issues have implications for discursive affordances in all realms of social life including political debate, and the infinite variety of social themes with which it is concerned.

\section{Emotionalisation of media discourse: Areas of exploration}

In a changed media landscape, we thus need to interrogate language and society along lines of enquiry that reflect the key themes outlined so far. Our special issue does this through the lens of emotionalisation, and from a critical perspective. 
Our exploration of the ways in which language framing may intersect with the emotionalisation of media discourse is guided by what we see as key questions that need addressing in particular around the whats, whys, and hows of media discourse. We would therefore like to put forward a media and emotions research agenda in relation to three key areas of exploration in which the whats, whys and hows of media discourse interplay significantly with each other.

The first area of exploration is concerned with the logics of media production and reception. Information and entertainment goals, along with social, political and commercial agendas, have always driven media production. While emotions have often been mobilised by the media to achieve those goals (for example by sensationalizing a piece of news to make it newsworthy, or to support one particular editorial line), one key question is how the media is now performing these functions in an ever-shifting social landscape. For example, how is the press performing its persuasive function in relation to, for instance, new multimodal and digital forms of communication? Crucially, moreover, for whose benefit or what political gain is this being done? Researching the emotionalisation of media discourse should therefore help us understand not only what discourses are produced by the media but also why they are circulated.

The role of the media in creating and swaying public opinion can hardly be overstated. Constructing and appealing to emotions must therefore largely be seen as instrumental to media persuasive strategies. For example, the question of 'moral panic', as fuelled and amplified by the media has been widely debated since the Sixties (Cohen 2011) and has now re-emerged around new discursive foci such as the politicization of the 'immigration debate', which has centered around emotional responses of fear and resentment (Kopytowska \& Chilton 2018, Wodak 2015, Zappettini 2019,2021). In this sense, the newsworthiness of media coverage should primarily be seen as lying in specific communicative agendas that ultimately respond to basic social anxieties (Delanty 2008) and fears of having 'strangers at our door' (Bauman 2016). If "the prevalence of fear in public discourse can contribute to stances and reactive social policies that promote state control and surveillance" (Altheide \& Michalowski 1999: 476), then we should also explain how the media mobilisation of fear-mongering, and other emotions, can also serve the legitimation of various political projects or commercial imperatives (see Cap 2017, Kopytowska \& Chilton 2018, Sedláková \& Kopytowska 2018, Doudaki \& Boubouka 2019, Koschut 2020, Ozyumenko \& Larina, this issue, Trajkova 2020).

Within this first area of exploration, we believe that the emotions play a crucial role, not only in how and why media discourses are produced but also in how and why they are received and consumed by their audiences. Although much research has shown how frequent exposure to certain media narratives can sediment into a 'cumulative effect' (Bell 1996) that would explain some readerships' attitudes, the direction of causality (who influences whom) between media and audience is not linear, and the 'media effect' (Wirth \& Schramm 2005) is better to be assumed as mutually constitutive (that is, the media reinforces certain views already formed 
among their audiences, who in turn select media aligned with their views). We would thus need to consider different potential discursive sites of production and consumption (van Dijk 1988) in which media emotionalisation is taking place.

The second area of exploration delves into the boundaries of media discourse. Here we would like to draw attention to at least two significantly interrelated trends. One trend is that, arguably, the tones of mediatized socio-political debates are shifting away from logos towards pathos or indeed towards the realm of irrealis statements. In other words, from reasoned debate about the issues of the day to a more direct appeal, based often on various forms of emotionality or constructs which are no longer connected with any truth-based logics, the so-called 'fake news' which is so pervasive in a post-truth society (D'Ancona 2017). However, even rejecting the claim for a diminished reliance on logos, Haidt's (2001) social intuition model tells us that moral reasoning is only subsequent to moral intuition (that is, a 'gut feeling' evaluation based on basic emotions), thus underlining the importance of pathos-oriented discourses. Emblematic of these processes are social media platforms such as Facebook and Twitter, which have enabled interaction by "shift[ing] the boundaries between private and public domains; [by] combin[ing] reflections of individual interiority with the process of making sense of social relations and the constitution of collective identity" (Lerner \& Rivkin-Fish 2021: 6). Social media such as Facebook and Twitter are to be seen not simply as platforms but rather as social and political actors/institutions in their own right, as they have the power to gatekeep and polarise debates and to control our interaction via algorithms which ultimately are based on our emotions. This raises questions around discursive opportunities and affordances, and more generally the institutionalization of social reality (Berger \& Luckman 1966).

Arguably, the appeal of recent US presidents such as Barack Obama and, to an even greater extent, Donald Trump, depended in no small measure to the way in which their emotional appeal, transmitted via the affordances of emergent technology, resonated with receivers in the intimacy of their relations with the new media platforms. With Trump, in particular, a new phenomenon was witnessed, in which the emotional responses of a political leader were directly transmitted to subjects - in a literal sense, followers - allowing for the bypassing of all the previously known filters that have always characterised traditional media. This phenomenon, which also highlights pathos over logos, was not limited to Trump, but has become a feature of political discourse more generally. Other social media platforms such as Youtube or Facebook have effected similar alterations, enabling for more direct engagement between the parties involved in the political process, and at the same time permitting the expression and exchange of emotive talk, which readily slips towards the high intensity end of the spectrum. Insults, critiques, dismissals, ad hominem attacks, rants, diatribes and feuds are more frequently encountered than their opposites - hyperbolic admiration, emoji-fuelled expressions of adoration or love, exaggerated praise or abbreviations signalling degrees of amusement (lol, lmao, etc.) - though the latter also feature. As Bassols, 
Cros \& Torrent (2013) suggest, both positive and negative emotions have the effect of capturing and holding the interest.

A second trend, namely the heightened emotionalization of media language regulation, also needs consideration. Ideologies and interests have been able to harness the power of new media such as social networks, for better or for worse. Such media affordances have the potential to appropriate the internet as a propaganda tool and, in some cases to promote hate speech, seemingly shifting the threshold of what is now sayable and accepted in the public sphere (Wodak 2019). In response, we are seeing increasing debates around issues of political correctness in language produced or allowed by the media (Assimakopoulos et al. 2018). The extent to which 'verbal hygiene' (Cameron 2012) should be applied (if at all) is not something that we can cover in the space of this article, however, as it involves the larger question of prescriptivism, but would be worth further investigation.

The third area of exploration covers the semiotic resources which have been deployed by the media, and their associated pragmatic implications. As linguists, semioticians and social scientists we need to adapt our investigation of "affectivediscursive practices" (Wetherell et al. 2015: 57) and strategies to the changing media landscape by focusing both on verbal means of construing emotionality through lexico-grammatical resources such as metaphor, simile and other rhetorical devices (Emanatian 1995, Handa 2013) and non-verbal means (font size, large text in headings, use of colour, pictures, etc.) recognizing thus the importance of multimodality in realising discourses (e.g. Dancygier \& Vandelanotte 2017, Ponton 2016). Arguably, the multimodal construction of meaning in the 'image-texts' (Mitchell 1986) encountered in memes (Denisova 2019, Mina 2019, Jus 2019), above all privileges the emotional dimension of communication. Indeed, through the symbolic language of emoticons it is possible for skilled users to communicate a range of emotional responses to posted content, and thus an interactive dimension is constructed that both permits and encourages the underlining of the emotional component. Though in its early stages, Multimodal theory (Kress \& Van Leeuwen 2010, Bateman et al. 2017, etc.) represents an invaluable contribution to the theoretical and practical approaches favoured in Discourse Analysis generally (Alba-Juez 2009, Ponton \& Larina 2016, 2017), since it aims at explicating meanings in the prevalent semiotic practices of the computer age. These frequently depend on the emergent codes, widely shared among the proficient, mainly young users of the new generations, inherent in colour, number and other forms of contemporary symbolism (Faliang et al. 2017). Finally, it is important to remember that any 'sign' (whether it be text or image), makes sense within a communicative context that must be shared by the producer and receiver of any message. As some of the contributions in this issue implicitly demonstrate (e.g. Musolff, Solopova \& Kushneruk, Zappettini) the semiotic resources tapped into by the media analysed in their studies are predicated on specific cultural repertoires that the analyst must interpret from an emic perspective. 


\section{Outline of contributions to the issue}

The contributions to this issue address some of the key issues outlined above and they do so from a variety of methodological approaches and with different analytical foci.

Bull and Waddle's contribution focuses on emotionality in audience responses to (televised) political speeches. Building on and extending Atkinson's work on interactive behaviour between speaker/audience, Bull and Waddle explore in detail dynamics of invited and uninvited audience responses (e.g. applause and booing) in a variety of national contexts. This study illuminates the subtle interplay between rhetorical techniques used by politicians to invite responses which, as claimed by the authors, may be seen to reflect differing degrees of audience emotionality. The significance of Bull and Waddle's paper is not simply based on propositional content but also largely depends on affective and emotional elements. The authors' analysis can thus be extended further to corroborate our understanding of political communication.

Our issue also features three papers that deal with emotionalization of media discourse in the debates and unfolding of events relating to Brexit. Musolff analyses a corpus of politicians' speeches and interviews and press texts in relation to the proverb 'You cannot have your cake and eat it' to argue that the hyperbolic use of such proverb was instrumental in driving highly emotional discourses associated with metaphorical scenarios of liberation (in the specific instantiation, the UK liberating itself from the EU's yoke). Musolff goes further, suggesting that the escalation of the cake metaphor - upon which many Leave and Remain arguments rested - "led to a polarisation and radicalisation of political discourse in Britain".

Similar views are put forward by Zappettini who, focusing on the language of the British tabloid press, shows how emotionally laden representations of Britain and the EU as victim and bully respectively drove many public discourses during the negotiation stages of Brexit. Zappettini also critically points to how the emotional language of the tabloid press has been instrumental in shaping public opinion on the UK/EU relationships not only in the context of Brexit but also in the larger historical coverage of Euro-news as it effectively managed to drive the Brexit agenda along 'pathos over logos' lines. Crucially, such emotional framing of Brexit also became the dominant discourse of the Leave campaign and gained traction visa-vis the Remain arguments which were primarily perceived as based on 'cold facts' (Zappettini 2019).

Dancygier's contribution also focuses on discourses of Brexit during the negotiation stage, looking in particular at emotional responses to narrativized similes ('Brexit is/feels like...'). However, rather than focusing on how emotions are construed in/by the media, Dancygier's analysis is concerned with how different similes, or 'patterns of figuration' can signal different stances. Dancygier gives us a detailed account of how similes were used by speakers/writers to communicate their different emotional stances on specific aspects of Brexit with a focus on how ordinary citizens conceptualized Brexit and how they responded to its delivery. 
Like Zappettini and Musolff, Dancygier demonstrates the relationships between linguistic forms and the emotional responses they are meant to convey, reasserting a view of media discourses as crucial in connecting citizens' attitudes and sociopolitical changes.

Lewandowska-Tomaszczyk and Pęzik explore the emotional impact of Polish media texts within an interpretative framework that views them as exemplifying the presence of an inherently persuasive, political function, which often manifests in covert rather than explicit ways. The paper outlines a theoretical innovation in the shape of the notion of 'emergent impoliteness', which is deployed to categorise examples from the representation of Polish political discourse. This method allows us to appreciate subtle shading in the instrumental use of the emotions in politics, where instances of overt rudeness or insulting language may be supplemented by nuanced innuendo which allows the politician to achieve emotional impact while maintaining an apparently polite public façade.

Three contributions focus on Russia, with two articles (Dobrosklonskaya, Solopova \& Kushneruk) dealing with the specific topic of Russian political communication and one (Ozyumenko \& Larina) with that of media discourse about Russia. Dobrosklonskaya's paper analyses press coverage of the 75th anniversary of victory in WWII, from a Media Linguistics, multimodal perspective, using a theorization of press functioning that dates back to the influential model proposed, in 1965 , by Galtung and Ruge. Drawing on a previous paper of her own (Dobrosklonskaya 2020), Dobrosklonskaya argues that the stage at which the press 'interpret' the events for their readers is the most relevant for focusing on emotional effects. The analysis enables us to appreciate the role of emotional discourse in fostering a sense of national unity; more precisely, that emotions are central in mediated political interpretations of significant public events.

While Dobrosklonskaya's study regards media discourse within Russia, Solopova and Kushneruk present a diachronic study that explores the role of emotional press discourse that centres on the image of Russia itself in western eyes, and how variance in these patterns across time reflects alterations in the geopolitical landscape. The study, like Dobrosklonskaya's, focuses on the Second World War, when Russia's status as a key ally in the fight against Nazi Germany encouraged the use of positive discursive frames regarding Russia, in press discourse emphasizing her heroic qualities, her military might, her friendship with Britain. The warmth of these representations may surprise readers more accustomed to see Russia framed as a bear with the "surly, uncouth, burly, shambling, enraged, violent" features of a wild animal, as she is apt to appear in contemporary press discourse. The study accounts for these changes and their corresponding emotional valences in terms of a theory that views press frames as subservient to wider political goals of the specific national groups in question.

Following on from this paper, that of Ozyumenko and Larina enlarges on its discussion of the innate social forces that drive such strategies of framing, arguing that we are witnessing an authentic strategy of emotional manipulation on the part 
of western media, in the service of creating fear of a so-called 'Russian threat', with the aim of justifying hard-line policies of containment and aggression. With ample reference to existing literature on the role of emotional discourse in political life, the paper uses data from British and American press sources to support its far-reaching thesis. As in the paper by Lewandowska-Tomaszczyk and Pęzik, the authors distinguish between implicit and explicit emotional effects, and also identify nuances, or degrees, of feeling in representations of political discourse regarding Russia. In terms of explicit effects, they discuss the press' use of idioms, hyperboles, metaphors, word play, cultural images and animalistic symbols. What emerges is a view of western media that, in recent times, has increased its reliance on emotional discourse, in collusion with a political class that has its own reasons for wishing to create a state of 'panic' about Russia amongst the general public.

Finally, the contributions of Ponton and Way point to how multimodality has been deployed in social media as a form of satire, parody, and critique. Their papers focus on memes as a new form of persuasive media discourse that has leveraged the emotions considerably. Way looks at public reactions to former US President Donald Trump as they were posted on an Alt-Right website, and finds that these memes lean on emotional discourses about nationalism, racism and authoritarianism. Significantly, Way reminds us that all memes are now part of a new politics which does "not communicate to us in logical arguments, but emotionally and affectively through short quips and images that entertain". This, of course, has often been the case with satire in the media but new ways of producing, distributing and consuming such messages, as well as the capability of multimodally combining different discursive forms should make us reflect on the extent to which both satire and extremist discourses are entangled with emotions and media. Ponton's work explores the pragmatic potentialities of this new communicative genre the meme, seeing them largely in terms of the traditional canons for political satire, i.e. 'speaking the truth to power'. Naturally, the emotional mainspring of these multimodal productions tends to be laughter, though nestling within this initial response are other emotions such as disgust, anger, frustration, fear, etc. Ponton's perspective on satirical political memes sees them as aligned with other persuasive political artefacts, subverting the viewers' opinions, and in ideal cases producing alignment. Like the viruses to which they are frequently compared, they may enter cognitive systems and produce their unpredictable effects largely without reference to the viewers' wishes or will.

\section{Concluding remarks}

As with many other types of scientific enquiry, our exploration of the emotionalisation of media discourse has only been able to provide a snapshot, rather than a full picture of the complex interplay between media, emotions and discourse. Nevertheless, we believe we have provided some solid evidence for how the mediatization of emotions is a feature of every-day social life and for how language (in its wider interpretation as a system of signs) and discourse (in its larger social ramifications) are inextricably part of it. 
By way of summarising the contribution of this Special Issue to the advancement of the literature in the field, we would like to highlight some of our key findings. We have suggested that emotionalisation has increasingly become one of the pivotal features of media discourse, and that this has primarily been achieved through a discursive shift from logos to pathos whereby rational arguments give way to the tendency to leverage on feelings. We have critically suggested that a crucial driver of this shift, and in general of the use of emotions by media actors, has been the aim of achieving effective persuasive strategies. Methodologically, we have demonstrated that adopting a critical approach (such as Critical Discourse Analysis) can help us understand the potential impact of such persuasive strategies and their pragmatic and perlocutionary effects on audiences and, more generally, on the implementation of specific political and ideological goals. These processes can only be fully explicated by taking the context and its socio-political, historical and cultural dimensions into account. To put it simply, an interdisciplinary approach to linguistic enquiry has numerous practical advantages. We have also highlighted the merit of exploring the analysis of emotional discourses via a multimodal approach that looks at language in its different semiotic realisations. As our studies show, such a diversity of methods and approaches should be helpful in triangulating and thus corroborating the interpretation of our results.

It is our hope that this Special Issue will not represent a terminus but rather a point of departure for future investigations of the emotionalisation of public discourse on the back of the research agenda that we have just outlined, and in the light of any topical issues that our societies will be faced with. We would particularly encourage any further research on the emotionalisation of media discourse that focuses on the production of emotions in different media (such as the press, TV, social media), and genres (news items, commentaries, interviews, political speeches, political debates, etc.), and their reception among different audiences.

The editors would like to take this opportunity to thank our contributors and compliment them on the quality of their contributions to this Special Issue. Thanks to them, a lively, interconnected debate has been presented on this topical issue, that will add to the growing body of linguistic research on these important themes. We are open to suggestions of the form these might take; seminars, conferences, individual or group initiatives, and so on. Most of all it is our hope that readers will be inspired by these papers to contribute their own research in these areas, and that they will find practical tools that will assist them with their analytical projects.

\section{RU}

\section{1. Введение}

Эмоции лежат в основе человеческого взаимодействия и общения, и, как свидетельствуют многочисленные исследования в области психологии, социологии и лингвистики, их роль в последние годы заметно возросла 
(см. например, Alba-Juez \& Larina 2018, Lerner \& Rivkin-Fish 2021, Mackenzie \& Alba-Juez 2019, Scherer 2005, Wetherell 2012, 2015, Волкова \& Панченко 2018, Шаховский 2008, 2018 и многие др.). Исследователи отмечают повсеместное присутствие эмоциональности в современной культуре, где «эмоции становятся более важными, чем что-либо еще» (Lerner \& Rivkin-Fish 2021: 1). Они показали, что как эксплицитные, так и имплицитные средства эмоциональности расширили свои функции в различных социальных сферах и дискурсах. Таким образом, термин эмоционализация используется для обозначения интенсификации и легитимации эмоций и эмоционального дискурса в общественных сферах жизни (Ahmed 2014, Holmes 2010, Lerner \& Rivkin-Fish 2021, Sieben \& Wettergren 2010, Woodward 2009). Как и в повседневном межличностном взаимодействии, эмоционализация наблюдается в институциональной, профессиональной и административной сферах (см. Lerner \& RivkinFish 2021). По наблюдениям исследователей, не являются исключением дипломатический, экономический и финансовый дискурсы, для которых обращение к эмоциям считается нехарактерным (например, Беляков 2015, Mackenzie 2018, Zappettini \& Unerman 2016). Эмоции играют существенную роль в академическом дискурсе (Gretzky \& Lerner 2021, El-Dakhsetal 2019, Larina \& Ponton 2020, Lerner, Zbenovich \& Kaneh-Shalit 2021). Некоторые ученые отмечают, что чрезвычайно сложно отделить эмоции от идеологии, поскольку чувства и идеи, которые их вызывают, тесно связаны друг с другом (Wetherell et al. 2015: 57). Как подчеркивает Р. Бриз (2020: 22), эмоции являются неотъемлемым компонентом политического дискурса именно из-за их эмоционального / аффективного воздействия на целевую аудиторию (см. также Breeze 2019). Эмоционализация широко распространена в средствах массовой информации (Alba-Juez \& Mackenzie 2019, Altheide 2002, 2006, Antipova et al. 2021, de Marlangeon 2018, Dövelingetal 2011, Furedi 2018, Schwab \& Schwender 2011, Vishnyakova \& Polyakova 2017 и др.), где эмоции используются как одно из важнейших средств убеждения. Их исследование необходимо для понимания того, как создаются сообщения, а также как они влияют на индивидуальное и социальное поведение и социальную жизнь общества в целом (Döveling et al. 2011).

Наш специальный выпуск посвящен отмеченным выше тенденциям и их проявлению в СМИ. Таким образом, наша цель состоит в том, чтобы исследовать эмоции в СМИ с семиотической, прагматической и дискурсивной точек зрения на фоне современного социально-политического контекста, где традиционные представления о роли СМИ, их профессиональных практиках претерпевают существенные изменения в результате применения новых технологий, которые создают возможности для более интерактивных форм общения, осуществляемых через социальные сети (Assimakopoulos et al. 2018, Bou-Franch \& Garcés-Conejos Blitvich 2019, Breeze 2020 и др.).

На фоне этих изменений мы видим появление новых возможностей (например, гражданская журналистика), которые демократизируют информационную функцию, обычно реализуемую в традиционных формах. Между 
тем современные медиаплатформы ставят новые задачи в отношении производства, распространения и потребления информации, поскольку различия между публичной и частной сферой становятся все более размытыми. Эти вопросы находят отражение в дискурсивных возможностях во всех контекстах общественной жизни, включая политические дебаты и дискуссии по разнообразным социальным темам.

\section{2. Эмоционализация медийного дискурса: области исследования}

В изменяющемся медиаландшафте взаимодействие языка и общества необходимо исследовать по намеченным основным направлениям. В нашем специальном выпуске это делается через призму эмоционализации. Исследование того, как языковой фрейм может пересекаться с эмоционализацией медийного дискурса, строится вокруг трех, на наш взгляд, ключевых вопросов, требующих ответа, а именно ЧТО, ПОЧЕМУ и КАК. Поэтому мы хотели бы предложить в качестве основных векторов исследований СМИ и эмоций три ключевые области, в которых «что», «почему» и «как» в значительной степени пересекаются.

Первая область исследования связана с логикой производства и восприятия медиапродукта. Информационные и развлекательные цели, наряду с социальной, политической и коммерческой повесткой дня, всегда лежали в основе медиапроизводства. Для достижения этих целей СМИ часто задействуют эмоции (например, путем создания сенсации в новостном сообщении). Однако возникает вопрос, как средства массовой информации выполняют эти функции в условиях постоянно меняющегося социального и политического ландшафта. Например, как пресса выполняет функцию убеждения с учетом новых мультимодальных и цифровых форм коммуникации? И главное, в чьих интересах и с какой политической целью? Таким образом, исследование эмоционализации медийного дискурса должно помочь нам понять не только то, какие дискурсы производятся средствами массовой информации, но и почему они производятся и распространяются.

Роль СМИ в формировании общественного мнения и влиянии на него трудно переоценить. В связи с этим формирование эмоций и обращение к ним должно в значительной степени рассматриваться как средство реализации стратегии убеждения. Например, «моральная паника» ('moral panic') (т.е. наведение паники по вопросу моральных норм поведения), подпитываемая и усиливаемая средствами массовой информации, широко обсуждается с шестидесятых годов (Cohen 2011). Теперь она фокусируется на новых темах, например, иммиграция и эмоциональный ответ на нее в виде страха и неприятия (Kopytowska \& Chilton 2018, Wodak 2015, Zappettini 2021). В этом смысле информационная ценность того или иного медийного освещения должна определяться в первую очередь тем, насколько она отвечает конкретной коммуникативной повестке дня, которая в конечном итоге реагирует на основные «социальные тревоги» (Delanty 2008) и страх перед «чужими» (Bauman 2016). 
Как известно, преобладание страха в публичном дискурсе может способствовать формированию определенного отношения и приводить к ответной социальной политике, что в итоге способствует усилению государственного контроля и надзора (Altheide \& Michalowski 1999: 476). Соответственно, мы также должны объяснить, как осуществляемое через СМИ нагнетание страха и обращение к другим эмоциям может служить легитимации различных политических и/или коммерческих проектов (см. Сap 2017, Doudaki \& Boubouka 2019, Kopytowska \& Chilton 2018, Koschut 2020, Ozyumenko \& Larina в этом выпуске, Sedláková \& Kopytowska 2018, Trajkova 2020).

В рамках первой проблемной области исследования одним из важнейших следует считать вопрос о решающей роли эмоций в том, как и почему создаются те или иные медиадискурсы. Однако не менее важным является и вопрос о том, как и почему они воспринимаются и потребляются аудиторией. Хотя многие исследования показали, как частое повторение определенных медийных нарративов может привести к «кумулятивному эффекту» (Bell 1996), который в итоге вызывает определенные отношения читателей, направление причинно-следственной связи (кто на кого влияет) между СМИ и аудиторией не является линейным и его лучше рассматривать как взаимно конституирующее. То есть СМИ укрепляют определенные взгляды, уже сформированные среди их аудитории, а аудитория затем предпочитает те СМИ, которые совпадают с ее взглядами. Таким образом, нам необходимо рассматривать различные потенциальные дискурсивные стороны производства и потребления (van Dijk 1988), в которых имеет место эмоционализация СМИ.

Вторая исследовательская область касается границ медиадискурса. Здесь мы хотели бы обратить внимание как минимум на две взаимосвязанные тенденции. Одна заключается в том, что тональность социально-политических медиадебатов смещается от логоса к пафосу или даже ирреалису, т.е. от аргументированных дебатов по актуальным проблемам - к более прямым заявлениям, часто основанным на различных формах эмоциональности или конструктах, которые не соответствуют действительности и не связаны с какой-либо логикой. Это так называемые фейковые новости, которые довольно широко распространены в «обществе постправды» (D'Ancona 2017). Однако, даже отвергая аргумент ради уменьшения зависимости от логоса, модель социальной интуиции Дж. Хайдта (Haidt 2001) говорит нам, что моральный аргумент является следствием моральной интуиции (то есть оценки, основанной на «внутреннем чувстве», которое в свою очередь базируется на эмоциях), тем самым подчеркивается важность ориентированных на пафос дискурсов.

Отражением этих процессов являются платформы социальных сетей, такие как Facebook и Twitter, сделавшие возможным взаимодействие, в котором сдвинуты границы между частным и общедоступным, где размышления о внутренней сущности сочетаются с осмыслением социальных отношений и созданием коллективной идентичности (Lerner \& Rivkin-Fish 2021: 6). Социальные сети следует рассматривать не просто как платформы, а как 
самостоятельные социальные и политические акторы / институты, поскольку они обладают способностью сдерживать и поляризировать дебаты и контролировать наше взаимодействие с помощью алгоритмов, которые в конечном итоге основаны на наших эмоциях. Это ставит вопросы о дискурсивных возможностях и в более общем плане - об институционализации социальной реальности (Berger \& Luckman 1966).

Можно утверждать, что степень симпатии к недавним президентам США - Бараку Обаме и, в еще большей степени, Дональду Трампу, в немалой степени зависела от того, каким образом их эмоциональная привлекательность, передаваемая через доступные новые технологии, находила отклик у аудитории, и от использования ими новых медиаплатформ. В частности, в случае с Трампом был зафиксирован новый феномен, когда эмоциональные реакции политического лидера напрямую передавались субъектам, в буквальном смысле - последователям, минуя все известные ранее фильтры, характерные для традиционных СМИ. Это не единичный пример, который также свидетельствует о доминировании пафоса над логосом. Данное явление в целом стало характерной чертой политического дискурса.

Другие социальные платформы, такие как Youtube и Facebook, тоже претерпели аналогичные изменения, допуская более прямое взаимодействие между сторонами, участвующими в политическом процессе, и позволяя обмениваться эмоциональными репликами, которые легко скатываются к крайней степени интенсивности. Оскорбления, резкая критика, нападки, личные выпады, тирады встречаются чаще, чем гиперболическое восхищение, преувеличенная похвала, выражения симпатии и любви, хотя последнее тоже имеет место. Исследователи отмечают, что, как положительные, так и отрицательные эмоции притягивают и удерживают интерес аудитории (Bassols, Cros \& Torrent 2013).

Таким образом, вторая из выделенных нами тенденций - это повышенная эмоционализация языка СМИ, регулирование которого также требует изучения. Новые медиа используются в качестве инструмента пропаганды для формирования различных идеологических установок. В некоторых случаях, например, для пропаганды языка вражды, считается возможным снижение порога допустимости того, что можно говорить в общественной сфере (Wodak 2019). В ответ мы наблюдаем усиление дебатов по проблеме политкорректности в языке СМИ (Assimakopoulos et al. 2018). Вопрос о том, до какой степени должна применяться «словесная гигиена» (Cameron 2012) (и должна ли она применяться), выходит за рамки данной статьи, так как он включает более широкую проблему прескриптивизма, которая заслуживает отдельного изучения.

Третья область исследования охватывает семиотические ресурсы, используемые СМИ, и связанные с ними прагматические импликации. Нам, лингвистам, семиотикам и социологам, необходимо адаптировать исследование «аффективно-дискурсивных практик» (Wetherelletal. 2015: 57) и стратегий к 
изменяющемуся медиаландшафту, сосредоточив внимание на вербальных средствах конструирования эмоциональности с помощью лексико-грамматических ресурсов, таких как метафора, сравнение и другие риторические приемы (Emanatian 1995, Handa 2013, Richardson 2007), и невербальных средствах (размер шрифта, размер заголовка, использование цвета, изображений и т.д.), тем самым признавая важность мультимодальности в реализации дискурсов (см. Dancygier \& Vandelanotte 2017, Ponton 2016). Мультимодальное построение смысла в «текстах-изображениях» (Mitchell 1986), встречающееся в мемах (Denisova 2019, Mina 2019), в первую очередь отдает предпочтение эмоциональному параметру коммуникации. Действительно, с помощью символического языка эмотиконов опытные пользователи могут передавать ряд эмоциональных реакций на размещенный контент, и таким образом создается интерактивное измерение, которое позволяет и поощряет наличие эмоционального компонента. Хотя Мультимодальная теория (Kress \& van Leeuwen 2010, Bateman et al. 2017 и др.) находится еще только на начальной стадии развития, она представляет собой неоценимый вклад, как теоретический, так и практический, в дискурс-анализ в целом (Alba-Juez 2009, Ponton \& Larina 2016, 2017), поскольку она направлена на объяснение значений в преобладающих семиотических практиках компьютерного века. Эти практики часто связаны с новыми кодами, заложенными в цвете, числах и других знаках современного символизма (Faliang et al. 2017) и широко распространены среди опытных, в основном молодых, пользователей нового поколения. Наконец, важно помнить, что любой знак (будь то текст или изображение) имеет смысл в определенном коммуникативном контексте, который должен быть общим у создателя и получателя сообщения. Как косвенно демонстрируют некоторые статьи этого выпуска (например, Музолф, Солопова и Кушнерук, Заппеттини), используемые в СМИ семиотические ресурсы основаны на культурно-специфичных системах, которые аналитик должен интерпретировать с эмической позиции, т.е. с позиции носителя конкретной культуры.

\section{3. Статьи этого выпуска}

Представленные в данном выпуске исследования, основанные на различных методологических подходах и имеющие разные аналитические фокусы, рассматривают ряд сформулированных выше ключевых вопросов.

Исследование Питера Булла и Мориса Уоддла посвящено эмоциональным реакциям телевизионной аудитории на речи политиков. Опираясь на работы М. Аткинсона по интерактивному поведению выступающего и аудитории и расширяя его подход, Булл и Уоддл детально исследуют динамику реакций аудитории (например, аплодисменты или освистывание) в различных национальных контекстах. Это исследование проливает свет на тонкое взаимодействие между риторическими приемами, используемыми политиками для получения реакции аудитории, которая, по мнению авторов, может рассматриваться как проявление разной степени ее эмоциональности. 
Значимость данного исследования в том, что в его фокусе не только пропозиции высказываний, но и в значительной степени аффективные и эмоциональные элементы, оно способствует пониманию политической коммуникации.

Три статьи выпуска посвящены эмоциональной окраске медийного дискурса, касающегося дебатов и событий, связанных с Брекситом. Известный исследователь политической метафоры Андреас Музолф (Musolff 2004, 2016, 2019) анализирует использование пословицы You cannot have your cake and eat $i t^{1}$ в газетных текстах, выступлениях и интервью политиков, чтобы доказать, что гиперболическое использование пословицы способствовало развитию высокоэмоциональных дискурсов, связанных с метафорическими сценариями освобождения (в конкретном случае - освобождения Великобритании от «гнета» Евросоюза). Музолф идет еще дальше и высказывает предположение о том, что распространение данной метафоры, на которой основывались многие аргументы в пользу того, чтобы выходить из Евросоюза или оставаться в нем, привело к поляризации и радикализации политического дискурса Великобритании.

Аналогичные идеи выдвигает и Франко Заппеттини, который, анализируя язык британской бульварной прессы, показывает, что эмоционально нагруженные представления о Великобритании как жертве и Евросоюзе как притеснителе, вызвали множество публичных дискуссий на этапах переговоров по Брекситу. Заппеттини указывает на важную роль эмоционального языка бульварной прессы в формировании общественного мнения об отношениях Великобритании и ЕС не только в контексте Брексита, но и в более широком историческом освещении евроновостей, поскольку он эффективно помогал повестке дня Брексита по принципу «пафос выше логоса». Важно отметить, что такое эмоциональное оформление Брексита стало доминирующим дискурсом кампании по выходу из Евросоюза в отличие от дискурса кампании против выхода, который был основан на «холодных фактах» (Zappettini 2019).

Барбара Данцигер также рассматривает дискурс Брексита на этапе переговоров. В фокусе ее внимания - эмоциональные реакции на нарративные сравнения 'Brexit is / feels like...' 2 . Она показывает, как сравнения могут сигнализировать о разном отношении к Брекситу. В статье подробно исследуется, как использовались подобные сравнения для выражения эмоциональной позиции по конкретным аспектам Брексита, делается акцент на том, как обычные граждане концептуализировали Брексит и как они отреагировали на его реализацию. Как Заппеттини и Музолф, Данцигер демонстрирует взаимосвязь между языковыми формами и предполагаемыми эмоциональными реакциями на них, подтверждая мнение об основополагающей роли СМИ

${ }^{1}$ Букв.: Ты не можешь одновременно иметь свой пирог и съесть его. Приблизительные русские аналоги этой пословицы - совместить несовместимое; пытаться усидеть на двух стульях.

2 Букв.: «Брексит - это / Брексит ощущается как ...»). 
в обеспечении связи между отношениями граждан и социально-политическими изменениями.

Барбара Левандовска-Томашчик и Петр Пензик исследуют эмоциональное воздействие польских медиатекстов, показывая, что они выполняют присущую им политическую функцию убеждения скорее при помощи скрытых, чем явных средств и способов. В статье рассматривается новое в теоретическом плане понятие «возникающая невежливость» (“emergent impoliteness"), которое используется для категоризации примеров, взятых из польского политического дискурса. Предложенный в исследовании метод позволил увидеть тонкие оттенки в использовании эмоций в политическом дискурсе, где случаи явной грубости или оскорбительной лексики могут быть дополнены намеками, двусмысленными выражениями, которые позволяют политику добиться желаемого эмоционального воздействия, сохраняя при этом явно вежливую публичную тональность.

Следующие три статьи посвящены российскому политическому дискурсу, а также дискурсу западных СМИ о России. В статье Т.Г. Добросклонской с позиций медиалингвистики и мультимодальности анализируется освещение 75-й годовщины победы в Великой отечественной войне. Автор использует теорию функционирования прессы (Galtung \& Ruge 1965) и, развивая идеи своей предыдущей статьи (Добросклонская 2020), утверждает, что этап, на котором пресса «интерпретирует» события для своих читателей, наиболее важен для эмоционального воздействия. Её анализ позволяет оценить роль эмоционального дискурса в воспитании чувства национального единства и показывает, что эмоции занимают центральное место в политической интерпретации значимых общественных событий в СМИ.

Если исследование Т.Г. Добросклонской касается медийного дискурса внутри России, то О.А. Солопова и С.Л. Кушнерук представляют диахроническое исследование, в котором рассматривается роль эмоционального прессдискурса, представляющего образ России в глазах Запада. В статье показано, как изменение этого образа во времени соотносится с изменениями в геополитическом ландшафте. Исследование, так же сосредоточено на Второй мировой войне, когда статус России как ключевого союзника в борьбе с нацистской Германией способствовал использованию позитивных дискурсивных фреймов в отношении России, в дискурсе прессы подчеркивались ее героические качества, военная мощь и дружба с Великобританией. Теплота этих представлений может удивить читателей, более привыкших видеть Россию в дискурсе современной прессы в образе медведя и с чертами угрюмого, неуклюжего, разъяренного и жестокого дикого животного. Авторы объясняют эти изменения и соответствующие им эмоциональные валентности с точки зрения теории, которая определяет рамки прессы как подчиненные более широким политическим целям конкретных национальных групп.

В следующей статье В.И. Озюменко и Т.В. Ларина продолжают анализ процессов, которые управляют стратегиями фрейминга, утверждая, что мы 
являемся свидетелями реального эмоционального манипулирования со стороны западных СМИ, служащих нагнетанию страха перед так называемой «российской угрозой» с целью оправдания жесткой и агрессивной политики сдерживания. Для подтверждения своего смелого тезиса авторы ссылаются на современную литературу о роли эмоционального дискурса в сфере политики и приводят многочисленные иллюстративные примеры из британской и американской прессы. Как и в статье Б. Левандовской-Томашчик и П. Пензика, авторы различают эксплицитные и имплицитные способы эмоционального воздействия, а также определяют нюансы и оттенки чувств в репрезентации политического дискурса о России. Среди эксплицитных средств воздействия обсуждается использование прессой идиом, гипербол, метафор, игра слов, культурные образы и анималистические символы, среди имлицитных рассматриваются пресуппозиция, вопросительные заголовки, проксимизация и др. Развивается тезис о том, что западные СМИ в последнее время все больше прибегают к эмоциональному дискурсу, обслуживая определенный политический класс, у которого есть свои причины поддерживать среди широкой публики состояние «паники» и страха в отношении России.

И, наконец, Дуглас Марк Понтон и Линдон Уэй показывают, как мультимодальность используется в социальных сетях в таких жанрах, как сатира, пародия и критика. В их статьях рассматриваются мемы как новая влиятельная форма медиадискурса, в значительной степени использующая эмоции. Понтон исследует прагматические возможности мемов, рассматривая их в основном с точки зрения традиционных канонов политической сатиры. Эмоциональной движущей силой этих мультимодальных сюжетов является смех, хотя за этой первоначальной реакцией скрываются и другие эмоции, такие как отвращение, гнев, страх и т.д. С точки зрения Понтона, сатирические политические мемы связаны с другими средствами воздействия. Они влияют на мнения зрителей и в идеальных случаях достигают своей цели. Подобно вирусам, с которыми их часто сравнивают, они проникают в сознание и в значительной степени добиваются своих непредсказуемых результатов независимо от желания или воли зрителей. Линдон Уэй рассматривает реакцию общества на бывшего президента США Дональда Трампа на сайте Alt-Right и показывает, что посвященные ему мемы основаны на эмоциональных дискурсах о национализме, расизме и авторитаризме. Примечательно, что Уэй напоминает нам, что мемы теперь являются частью новой политики, которая «общается с нами не логическими аргументами, а эмоционально через короткие шутки и забавные образы». Сатира, конечно, часто встречается в СМИ, но новые способы создания, распространения и потребления таких сообщений, а также возможность мультимодального комбинирования различных дискурсивных форм должны заставить нас задуматься не только о том, как сатира, но и как экстремистские дискурсы переплетаются с эмоциями и СМИ. 


\section{4. Заключение}

Мы не претендуем на то, что наш специальный выпуск, посвященный эмоционализации медиадискурса, дает полную картину сложного взаимодействия между медиа, эмоциями и дискурсом. Мы лишь очертили основные области исследований и попытались ответить на ряд актуальных вопросов. Тем не менее, мы полагаем, что представили убедительные доказательства того, что медиатизация эмоций стала особенностью повседневной социальной жизни, и показали, как эмоционализация СМИ реализуются через язык (в его более широкой интерпретации как системы знаков) и дискурс (в его широких социальных ответвлениях).

Подводя итоги обсуждения данной темы, мы хотели бы выделить некоторые из основных результатов. Предложенные исследования свидетельствуют о том, что эмоционализация становится одной из основных черт медиадискурса, и это в первую очередь достигается за счет дискурсивного перехода от логоса к пафосу, когда рациональные аргументы уступают место тенденции воздействовать на чувства аудитории. Мы полагаем, что решающим фактором этого сдвига и в целом использования эмоций акторами медиа является поиск эффективных стратегий убеждения. Что касается методологии, мы продемонстрировали, что критический дискурс-анализ может помочь понять потенциальное влияние стратегий убеждения и их прагматическое и перлокутивное воздействие на аудиторию и, в более общем плане, на реализацию конкретных политических и идеологических целей. Эти процессы могут быть полностью объяснены только с учетом контекста и его социально-политических, исторических и культурных аспектов, что говорит о том, что междисциплинарный подход к лингвистическому исследованию имеет множество практических преимуществ. Мы также подчеркнули необходимость анализа эмоциональных дискурсов с помощью мультимодального подхода, который рассматривает язык в его различных семиотических реализациях. Как показывают наши исследования, такое разнообразие методов и подходов может дать надежные результаты.

Мы надеемся, что этот специальный выпуск станет стимулом для будущих исследований эмоционализации публичного дискурса в намеченных нами направлениях и в свете актуальных социальных и политических проблем современного общества. Представляются перспективными дальнейшие исследования эмоций в различных видах СМИ (пресса, телевидение, радио, социальные сети и др.) и жанрах (новости, комментарии, интервью, политические выступления, политические дебаты и др.) и анализ их восприятия различными аудиториями.

Мы хотели бы воспользоваться этой возможностью, чтобы поблагодарить всех авторов за поддержку нашего проекта и высокое качество присланных статей. Благодаря вашему участию нам удалось провести живую дискуссию, которая пополнит междисциплинарные лингвистические исследования по этой важной теме. Мы надеемся на продолжение сотрудничества 
и открыты для предложений о том, какую форму оно может принять: семинары, конференции, индивидуальные или групповые инициативы и так далее. Больше всего мы надеемся, что наш специальный выпуск вдохновит читателей на проведение исследований в этих областях и что они найдут в нем практические инструменты, которые помогут в реализации аналитических проектов.

(C) Franco Zappettini, Douglas M. Ponton and Tatiana V. Larina, 2021 cc)creative

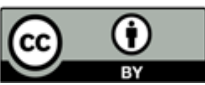

This work is licensed under a Creative Commons Attribution 4.0 International License https://creativecommons.org/licenses/by/4.0/

\section{Acknowledgments}

This publication has been supported by the RUDN University Strategic Academic Leadership Programme.

\section{REFERENCES}

Ahmed, Sara. 2014. The Cultural Politics of Emotion. 2 ed-n. Routledge.

Alba-Juez, Laura. 2009. Perspectives on Discourse Analysis. Theory and practice. Cambridge Scholars Publishing.

Alba-Juez, Laura \& Tatiana Larina. 2018. Language and emotion: Discourse-pragmatic perspectives. Russian Journal of Linguistics. (Special issue: The Discourse of Emotion). 22 (1), 9-37. https://doi.org/10.22363/2312-9182-2018-22-1-9-37

Alba-Juez, Laura \& J. Lachlan Mackenzie. 2019. Emotion, lies and bullshit in journalistic discourse: The case of fake news. Ibérica 38. 17-50.

Altheide, David. 2002. Creating Fear: News and the Construction of a Crisis. New York: Aldine de Gruyter.

Altheide, David L. 2006. Terrorism and the Politics of Fear. Lanham, MD: Alta Mira Press.

Altheide, David \& Sam Michalowski. 1999. Fear in the news: A discourse of control. The Sociological Quarterly 40 (3). 475-503.

Antipova, Alina S., Maria D. Rabeson \& Olga V. Smirnova. 2021. Semantic shift in conflict terminology in contemporary Russian socio-cultural media discourse. Training, Language and Culture 5 (2). 73-89. https://doi.org/10.22363/2521-442X-2021-5-2-73-89

Assimakopoulos, Stavros, Fabienne H. Baider \& Sharon Millar. 2018. Online hate speech in the European Union: a discourse-analytic perspective. Springer.

Barlett, Christopher \& Douglas Gentile. 2011. Affective and emotional consequences of the mass media. In Döveling, Katrin, Christian von Scheve, and Elly A. Konijn (eds.), The Routledge Handbook of Emotions and Mass Media. London and New York: Routledge. 60-78.

Bassols, Margarida, Anna Cros \& Anna M. Torrent. 2013. Emotionalization in new television formats of science popularization. Pragmatics 23 (4). 605-632.

Bateman, John, Janina Wildfeuer \& Tuomo Hiippala 2017. Multimodality: Foundations, Research and Analysis - A Problem-Oriented Introduction. Berlin: Mouton de Gruyter.

Bauman, Zygmunt. 2016. Strangers at Our Door. Polity.

Bell, Alan. 1996. The language of news media. Oxford: Blackwell. 
Belyakov, Mikhail V. 2015. Emotive character of diplomatic discourse. Russian Journal of Linguistics 2. 11-17. (In Russ.)

Berger, Peter \& Thomas Luckmann. 1966. The Social Construction of Reality: A Treatise in the Sociology of Knowledge. New York: Penguin.

Bou-Franch, Patricia \& Pilar Garcés-Conejos Blitvich (eds.). 2019. Analyzing digital discourse: New Insights and Future Directions, 105-131. Palgrave Macmillan, Cham.

Breeze, Ruth. 2019. Emotion in politics: Affective-discursive practices in UKIP and Labour. Discourse \& Society 3 (10). 24-43.

Breeze, Ruth. 2020. Angry tweets: A corpus-assisted study of anger in populist political discourse. Journal of Language Aggression and Conflict 8 (1). 118-145.

Cap, Piotr (ed.). 2017. The Language of Fear: Communicating Threat in Public Discourse. London: Palgrave Macmillan. https://doi.org/10.1057/978-1-137-59731-1

Cohen, Stanley. 2011. Folk Devils and Moral Panics. London: Routledge.

Cameron, Deborah. 1995. Verbal Hygiene. London: Routledge.

d'Ancona Matthew. 2017. Post-Truth: The New War on Truth and How to Fight Back. Random House.

Dancygier, Barbara \& Lieven Vandelanotte. 2017. Internet memes as multimodal constructions. Cognitive Linguistics 28(3). 565-598.

Denisova, Anastasia. 2019. Internet Memes and Society: Social, Cultural, and Political Contexts. NewYork\&London: Routledge.

Delanty, Gerard. 2008. Fear of others: Social exclusion and the European crisis of solidarity. Social Policy and Administration 42(6). 676-690.

de Marlangeon, Silvia Kaul. 2018. Fustigation, impoliteness, emotions and extimacy in Argentinian media celebrities. Russian Journal of Linguistics 22(1). 161-174.

Dobrosklonskaya, Tatiana G. 2020. Medialingvistika: teoriya, metody, napravleniya. Moscow: KDU "Dobrosvet" (In Russ.)

Doudaki, Vaia \& Boubouka Angeliki. 2019. Discourses of Legitimation in the News: The Case of the Economic Crisis in Greece (1st ed.). Routledge. https://doi.org/10.4324/ 9780429061325

Döveling, Katrin, Christian von Scheve \& Elly A. Konijn (eds.). 2011. The Routledge Handbook of Emotions and Mass Media. London and New York: Routledge.

El-Dakhs, Dina Abdel Salam, Fatima Ambreen, Maria Zaheer \& Yulia Gusarova. 2019. A pragmatic analysis of the speech act of criticizing in university teacher-student talk: The case of English as a lingua franca. Pragmatics 29 (4). 493-520.

Emanatian, Michele. 1995. Metaphor and the expression of emotion: The value of cross-cultural perspectives. Metaphor and Symbolic Activity 10 (3). 163-182.

Faliang Huang, Shichao Zhang, Jilian Zhang \& Ge Yu. 2017. Multimodal learning for topic sentiment analysis in microblogging. Neurocomputing 253. 144-153.

Furedi, Frank. 2018. How Fear Works: Culture of Fear in the Twenty-First Century. London: Bloomsbury Publishing.

Gammerl, Benno. 2012. Emotional styles - concepts and challenges." Rethinking History 16(2). 161-175. https://doi.org/10.1080/13642529.2012.681189

Gretzky, Maria \& Julia Lerner. 2021. Students of academic capitalism: Emotional dimensions in the commercialization of higher education. Sociological Research Online. 26 (1) 205-221. https://doi.org/10.1177/1360780420968117

Haidt, Jonathan. 2001. The Emotional dog and its rational tail: A social intuitionist approach to moral judgment. Psychological Review 108 (4). 814-834.

Handa, Carolyn 2013. The Multimediated Rhetoric of the Internet: Digital Fusion. New York: Routledge. 
Holmes, Mary. 2010. The emotionalization of reflexivity, Sociology 44 (1). 139-154. https://doi.org/10.1177/0038038509351616

Kopytowska, Monika \& Paul Chilton. 2018. "Rivers of blood": Migration, fear and threat construction Lodz Papers in Pragmatics 14 (1). 133-161. Special issue on Narrating hostility, challenging hostile narratives. https://doi.org/10.1515/lpp-2018-0007

Koschut, Simon. 2020. The power of emotions in world politics. London and New York: Routledge.

Kress, Gunther, R. \& Theo van Leeuwen. 2010. Reading Images: The Grammar of Visual Design. London and New York: Routledge.

Larina, Tatiana, Vladimir Ozyumenko \& Douglas M. Ponton. 2020. Persuasion strategies in media discourse about Russia: Linguistic ambiguity and uncertainty. Lodz Papers in Pragmatics 15 (1). 3-22. https://doi.org/10.1515/lpp-2019-0002

Larina, Tatiana \& Douglas Mark Ponton. 2020.Tact or frankness in English and Russian blind peer reviews. Intercultural Pragmatics 17 (4). 471-496.

Larina, Tatiana \& Douglas Mark Ponton. (forthcoming). I wanted to honour your journal, and you spat in my face: Emotive (im)politeness and face in the blind peer review genre. Journal of Politeness Research.

Lerner, Lulia \& Michele Rivkin-Fish. 2021. On emotionalisation of public domains. Emotions and Society. 3 (1). 1-11. https://doi.org/10.1332/263169021X16149420145743

Lerner, Julia, Claudia Zbenovich \& Tamar Kaneh-Shalit. 2021. Changing meanings of university teaching: The emotionalization of academic culture in Russia, Israel, and the USA. Emotions and Society. Special Issue Emotionalization of public domains. 3 (1). 73-93.

Mackenzie, J. Lachlan. 2018. Sentiment and confidence in financial English: A corpus study. Russian Journal of Linguistics 22 (1). 80-93.

Maíz-Arévalo, Carmen. 2018. Emotional self-presentation on WhatsApp: Analysis of profile status. Russian Journal of Linguistics. 22 (1). 144-160.

Mackenzie, J. Lachlan \& Laura Alba-Juez (eds.). 2019. Emotion in Discourse. Amsterdam and Philadelphia: John Benjamins.

Mina, An, Xiao. 2019. Memes to Movements: How the World's Most Viral Media is Changing Social Protest and Power. Ebook: Beacon Press.

Mitchell, William \& Thomas John. 1986. Iconology: Image, Text, Ideology. Chicago: University of Chicago Press.

Musolff, Andreas. 2004. Metaphor and political discourse: Analogical reasoning in debates about Europe. Palgrave Macmillan.

Musolff, Andreas. 2016. Political Metaphor Analysis: Discourse and Scenarios. Bloomsbury Publishing.

Musolff, Andreas. 2019. Creativity in metaphor interpretation. Russian Journal of Linguistics, 23 (1), 23-39. https://doi.org/10.22363/2312-9182-2019-23-1-23-39

Ponton, Douglas. 2016. Movement and meaning: Towards an integrated approach to political discourse analysis. Russian Journal of Linguistics. Special issue: Discourse Analysis in the 21st Century: Theory and Practice (I). 20 (4). 122-139.

Ponton, Douglas \& Tatiana Larina. 2016. Discourse analysis in the 21-th century: Theory and practice (I). Russian Journal of Linguistics. 20 (4). 7-25.

Ponton, Douglas \& Tatiana Larina. 2017. Discourse analysis in the 21-th century: Theory and practice (II). Russian Journal of Linguistics 21 (1). 7-21

Richardson, John E. 2007. Analysing Newspapers: An Approach from Critical Discourse Analysis. London: Palgrave Macmillan.

Schwab, Frank \& Clemens Schwender. 2011. The descent of emotions in media. Darwinian perspectives. In K. Döveling, Ch. von Scheve, and E.A. Konijn (eds.), The Routledge Handbook of Emotions and Mass Media, 15-36. London and New York: Routledge. 
Scherer, Klaus R. 2005. What are emotions? And how can they be measured? Social Science Information 44(4). 695-729. https://doi.org/10.1177/0539018405058216

Sedláková, Renáta \& Monika Kopytowska. 2018. Different faces of the unknown: The media and the semiotics of fear. In Monika Kopytowska \& Artur Gałkowski (eds.), Current Perspectives in Semiotics: Texts, Genres and Representations, 262-291. Frankfurt: Peter Lang.

Sieben, Barbara \& Asa Wettergren (eds.). 2010. Emotionalizing Organizations and Organizing Emotions. Basingstoke: Palgrave Macmillan.

Shakhovsky, Viktor. 2008. Linguistic theory of emotions. Moscow: Gnozis Publ. (In Russ.)

Shakhovsky, Viktor. 2018. The Cognitive Matrix of Emotional-Communicative Personality. Russian Journal of Linguistics 22 (1). 54-79. https://doi.org/10.22363/2312-9182-201822-1-54-79

Trajkova, Zorica. 2020. Media fraiming of the Macedonia name change issue: The use of fearinducing language strategies. Lodz Papers in Pragmatics 16 (2). 265-284.

Van Dijk, Teun Adrian. 1988. News as Discourse. Hillsdale, New Jersey: Lawrence Erlbaum.

Volkova, Yana \& Panchenko, Nadezhda. 2018. Discourse variation of the concepts of destructive emotions. Russian Journal of Linguistics 22 (1). 175-194. https://doi.org/ 10.22363/2312-9182-2018-22-1-175-194 (In Russ.).

Vishnyakova, Olga D. \& Natalia V. Polyakova. 2017. Linguistic and functional cognitive peculiarities of media language as the basis of interpretations in the communicative sphere. Training, Language and Culture 1 (2). 86-101. https://doi.org/10.29366/2017tlc.1.2.6

Yus, Francisco. 2018. Attaching feelings and emotions to propositions. Some Insights on irony and Internet communication Russian Journal of Linguistics 22 (1). 64-107.

Yus, Francisco. 2019. Multimodality in memes: A cyberpragmatic approach. In Patricia BouFranch Pilar Garcés-Conejos Blitvich (eds.). Analyzing digital discourse: New Insights and Future Directions, 105-131. Palgrave Macmillan, Cham

Wetherell, Margaret. 2012. Affect and Emotion: A New Social Science Understanding. London: Sage. https://doi.org/10.4135/9781446250945

Wetherell, Margaret. 2015. Trends in the turn to affect: A social psychological critique. Body \& Society 21(2). 139-166. https://doi.org/10.1177/1357034X14539020

Wirth, Werner \& Holger Schramm. 2005. Media and Emotions. Communication Research Trends. 24 (3). 1-39.

Wodak, Ruth. 2015. The Politics of Fear: What Right-Wing Populist Discourses Mean. London: Sage.

Wodak, Ruth. 2019. 'The boundaries of what can be said have shifted': An expert interview with Ruth Wodak (questions posed by Andreas Schulz). Discourse \& Society. Online first, December 2019. 1-10.

Wodak, Ruth. 2020. 'The boundaries of what can be said have shifted': An expert interview with Ruth Wodak (questions posed by Andreas Schulz). Discourse \& Society 31 (2). 235-244. https://doi.org/10.1177/0957926519889109

Woodward, Kathleen. 2009. Statistical Panic: Cultural Politics and Poetics of the Emotions, Durham, NC: Duke University Press.

Zappettini, Franco. 2019. The Brexit referendum: How trade and immigration in the discourses of the official campaigns have legitimised a toxic (inter)national logic. Critical Discourse Studies 16 (4). 403-419.

Zappettini, Franco. 2021. The tabloidization of the Brexit campaign: Power to the (British) people?' Journal of Language and Politics 20 (2). 277-303. https://doi.org/10.1075/ jlp.19103.zap

Zappettini, Franco \& Jeffrey Unerman. 2016. "Mixing" and "Bending": The recontextualisation of discourses of sustainability in integrated reporting. Discourse \& Communication 10 (5). $521-542$. 
Article history:

Received: 15 June 2021

Accepted: 30 August 2021

\section{История статьи:}

Дата поступления в редакцию: 15 июня 2021

Дата принятия к печати: 30 августа 2021

\section{Bionotes:}

Franco ZAPPETTINI is a Lecturer and Director of Postgraduate Research in Communication and Media at the University of Liverpool, UK. His research focuses on the textual/discursive analysis of different forms of political and organisational communication including mediated forms of populism, such as tabloid populism and Euroscepticism in the British press. He has published internationally in peer-reviewed journals and book series. His latest publication is the monograph Brexit: A Critical Discursive Analysis forthcoming for Palgrave MacMillan.

\section{Contact information:}

University of Liverpool

Foundation Building, Brownlow Hill, Liverpool, L69 7ZX, UK

e-mail: franco.zappettini@liverpool.ac.uk

ORCID: 0000-0001-7049-4454

Douglas Mark PONTON is Associate Professor of English Language and Translation at the Department of Political and Social Sciences, University of Catania. His research interests include political discourse analysis, ecolinguistics, sociolinguistics, applied linguistics, pragmatics and critical discourse studies. Recent publications include For Arguments Sake: Speaker Evaluation in Modern PoliticalDiscourse and Understanding Political Persuasion: Linguistic and Rhetorical Aspects. As well as politics, his research deals with a variety of social topics including tourism, the discourse of mediation, ecology, local dialect and folk traditions, including proverbs and the Blues.

\section{Contact information:}

University of Catania

Via Vittorio Emanuele II 49, Catania, 95131, Italy

e-mail:dmponton@gmail.com

ORCID: 0000-0002-9968-1162

Tatiana V. LARINA is Doctor Habil., Full Professor at RUDN University. Her research interests embrace language, culture and communication; cross-cultural pragmatics, discourse analysis, communicative ethnostyles, and (im)politeness theory with the focus on English and Russian languages. She has authored and co-authored over 200 publications in Russian and English including monographs, course books, book chapters and articles in peer-reviewed journals.

\section{Contact information:}

Peoples' Friendship University of Russia (RUDN University)

6 Miklukho-Maklaya, Moscow, 117198, Russia

e-mail: larina-tv@rudn.ru

ORCID: 0000-0001-6167-455X 
Сведения об авторах:

Франко ЗАППЕТТИНИ имеет степень доктора, преподает в Ливерпульском университете, Великобритания, руководит аспирантскими программами в области коммуникации и СМИ. Его исследования сосредоточены на текстуальном/дискурсивном анализе различных форм политической коммуникации, включая опосредованные формы популизма, такие как таблоидный популизм и евроскептицизм в британской прессе. Он публикует свои исследования в рецензируемых международных журналах и монографиях. Его последняя публикация - монография Brexit: A Critical Discursive Analysis (PalgraveMacMillan).

\section{Контактная информация:}

University of Liverpool

Foundation Building, Brownlow Hill, Liverpool, L69 7ZX, UK

e-mail: franco.zappettini@liverpool.ac.uk

ORCID: 0000-0001-7049-4454

Дуглас Марк ПОНТОН - профессор, преподаватель английского языка и перевода на кафедре политических и социальных наук в Катанийском университете (Италия). Сфера его научных интересов включает анализ политического дискурса, эколингвистику, социолингвистику, прикладную лингвистику, прагматику и критический дискурс-анализ. Его последние публикации: For Arguments Sake: Speaker Evaluation in Modern Political Discourse («Во имя аргументов: оценка оратора в современном политическом дискурсе») и Understanding Political Persuasion: Linguistic and Rhetorical Aspects («Способы убеждения в политике: лингвистические и риторические аспекты»). Наряду с политикой интересы Д.М. Понтона связаны с социальной тематикой: туризмом, дискурсом медиации, экологией, местными диалектами, народными традициями, пословицами и блюзом.

\section{Контактнаяинформация:}

University of Catania

Via Vittorio Emanuele II 49 Catania, 95131, Italy

e-mail:dmponton@gmail.com

ORCID: 0000-0002-9968-1162

Татьяна Викторовна ЛАРИНА - доктор филологических наук, профессор Российского университета дружбы народов (РУДН). Ее исследовательские интересы включают взаимодействие языка, культуры и коммуникации, кросс-культурную прагматику, дискурс-анализ, межкультурную коммуникацию, коммуникативную этностилистику и теорию не/вежливости. Она является автором и соавтором более 200 публикаций на русском и английском языках, включая монографии, учебники, главы книг, а также многочисленные статьи, в том числе в ведущих международных журналах.

\section{Контактная информация:}

Российский университет дружбы народов

Россия, 117198, Москва, ул. Миклухо-Маклая, 6

e-mail: larina-tv@rudn.ru

ORCID: 0000-0001-6167-455X 